\title{
Türk Kültür ve Devlet Geleneğinde Kadın
}

\author{
HASAN ACAR* \\ hasanacar.uludag@gmail.com \\ ORCID-ID: 0000-0001-2345-6789
}

\begin{abstract}
Öz: İnsanoğlunun ataları olarak kabul edilen Âdem ile Havva'dan beri "kadın" doğanın ve yaşam şartlarının tüm zorluklarına rağmen dünya üzerinde var olmuştur. "Kadın", bu varliğını sürdürmek için sürekli bir mücadele içerisinde bulunmuştur. Bu mücadelenin boyutu, her toplumun kadına olan farkl yaklaşımıyla şekillenmiştir. Dünya medeniyeti içerisinde, Türk kültür ve devlet geleneğinde "kadın” önemli bir değere sahiptir. Bu değerin ortaya çıkmasında şüphesiz Türk kültürünün sahip olduğu geleneksel bakış açısı büyük rol oynamıştır. Günümüz dünyasında ortaya çıkan hızlı teknolojik ve toplumsal değişimlerin etkisiyle Türk kültür ve geleneğinde "kadın", toplumun sağlam temeller üzerinde inşa edilmesi ve aile yapısının sağliklı bir şekilde devam etmesi için çok önemli role sahiptir. Bu çalışma, Eski Türklerden günümüze kadar geçen sürede"kadın"ın devlet ve toplum açısından taşıdığı önemi ifade etmeyi amaçlamaktadır.
\end{abstract}

Anahtar kelimeler: Türk devlet geleneği, Türk kültürü, Toplumsal değişim, Türklerde kadın, Kadınin toplumsal rolü.

\section{Giriş̧}

Bu çalışma, geçmişten günümüze Türk kültür ve devlet geleneğinde kadın konusunu ele almaktadır. Türklerin yazıya geçiş sürecinden önceki kaynakları genellikle efsane ve hikâyeler ile dönemi yaşayan seyyahların nesilden nesile aktarılan gözlemlerinden oluşmaktadır. Türklerde kadın, tarih boyunca sadece sosyal hayatta değil siyasi hayatta da önemli rol oynamıştır. Bunun yanında kadınların rolü dine, kültüre, toplum yapısına ve zamana göre değişiklikler göstermiştir. Aileyi oluşturan temel unsurlardan biri kadındır. Ailenin kendi arasında sürdürdüğ̈̈ birliktelik toplum için önemli bir etkendir. Çünkü aile iyi olursa toplum, toplum iyi olursa da devlet uzun süre ayakta kalacaktır.

Kültür, bir milleti millet yapan değerler arasında yer almaktadır. "Bir milletin kimliğini oluşturan unsurların tümü” olarak tanımlanan kültür kavramı, toplumda kadına

\footnotetext{
* Dr., Jandarma ve Sahil Güvenlik Akademisi Başkanlığı, Işıklar Jandarma Astsubay Meslek Yüksek Okulu.
} 
verilen değer ölçüsünde gelişme göstermiştir. ${ }^{1}$ İlkçağ medeniyetlerinde kadına isim dahi verilmezken, Türkler kadına her zaman değer vermiş, siyasi ve sosyal hayatta önemli görevlere getirmiştir. Eski Türk devlet geleneğinde kadın ile erkek insani değerler açısından eşit haklara sahip olarak kabul edilmiştir. Bu eşitlik, tüm sosyal hayatı kapsamamakla birlikte genel olarak günümüze kadar devamlılığını sürdüren bir anlayışın temelini oluşturmuştur. Kadınlar, doğuştan gelen biyolojik ve fiziksel yaradılışlarının üstünde erkeklere mahsus işleri de tarih boyunca yerine getirmiştir.

Türklerin İslamiyet’e girmesi ile birlikte kadının önemi daha çok artmıştır. Bu dönemde kadınlara verilen önem, kadınların sosyal ve siyasi statülerinin ilerlemesi ile sonuçlanmıştır. Bu çalışmada, Türk kültür ve devlet geleneğinde kadının yerini tarihsel ve sosyolojik bir süreç içerisinde; "Eski Türk Devlet Geleneğinde Kadın", "İslamiyet Sonrasında Türk Kadını", "Osmanlı Devleti’nde Türk Kadını” ve "Cumhuriyet’in İlanından Sonra Türk Kadını” olmak üzere dört başlık altında inceleyeceğiz.

\section{Eski Türk Devlet Geleneğinde Kadın}

İnsanlık tarihinin ilk dönemlerinde kadınlar dünyaya rahimlerinde taşıdıkları yeni bir canlıyı getirmeleri, fiziksel yapıları itibarıyla erkeklerden farklı bir takım özellikler göstermeleri ve fikri olarak hassas bir yapıda olmaları nedeniyle "gizli bilgilere sahip bir varlık” şeklinde değerlendirilmiştir. Türk şaman anlatılarında da yer alan bu durum, en güçlü ve korkunç şamanların kadınlar arasından çıktığı şeklinde ifade edilmiştir. Erkeklik ve kadınlık doğuştan gelen doğal bir durum olmakla birlikte bunun nasıl yaşandığını içinde bulunulan toplum belirler. Eski çağ ve Orta Çağda Türk kadını belli bir mekâna hapsolmaktan ziyade Avrupa’da yaşayan diğer kadınlara göre toplum içerisinde ve devlet yönetiminde oldukça aktif bir rol oynamıştır. ${ }^{2}$

Tarihte birçok toplum, güçlü bir aile yapısına sahip olmadıklarından ötürü tarih sahnesinden yok olup gitmiştir. ${ }^{3}$ Ancak Eski Türk devlet geleneğinde durum tam tersidir. Eski Türklerin kadına verdiği önemi, o dönemde başka hiçbir topluluğun vermediğini ifade etmek abartı olmayacaktır. Bilinen en eski Türkçe kaynak olan Orhun Abideleri'nden Kültigin Abidesi'nde, Tanrı'nın Türk milleti yok olmasın diye yarattığı kişiler arasında ikinci Göktürk devletinde kağanın eşi İlbilge Hatun'un adına yer verilmiştir. Eski Türk devlet geleneğinde kadının siyasi konumu gösteren bu durum, Türk toplumunda kadına verilen değerin bir ifadesi olarak değerlendirilmiştir. ${ }^{4}$ Kadının mevkiine dair bir örnek vermek gerekirse; Bilge Kağan kitabesinde: "Tanrı Türk milleti yok olmasın diye babam İl-teriş Kağan ile anam İl-bilge Hatun'u yükseltti” ifadesi, Türk kültüründe kadının siyasi ve toplumsal değerinin ne kadar yüksek olduğunu göstermektedir. ${ }^{5}$

1 Ayfer Yılmaz, “Türk Kültüründe Kadın”, Milli Folklor, 61 (2004), s.111.

2 Fuzuli Bayat, Türk Kültüründe Kadın Şamanlar, İstanbul: Ötüken Neşriyat, 2018, s.21-22.

3 Ahmet Gündüz, "Tarihi Süreç İçerisinde Türk Toplumunda ve Devletlerinde Kadının Yeri ve Önemi”, The Journal of Academic Social Science Studies, 5/5 (2012), s.130.

4 İbrahim Tellioğlu, İslam Öncesi Türk Toplumunda Kadının Konumu Üzerine, A.Ü. Türkiyat Araştırmaları Enstitüsü Dergisi [TAED], 55 (2016), s.219.

5 İbrahim Kafesoğlu, Türk Milli Kültürü, İstanbul, 2015, s.141. 
Türk mitolojisi içerisinde kadınların lider bir profil taşıdıkları yönünde birçok anlatı yer almaktadır. Bunların en başında Türklerin anaerkil bir toplumsal yapıya sahip oldukları yönünde özelliklerin yer aldığı Umay Ana miti ve İskitlerin kadın hükümdarı Tomris Han'ın liderlik özellikleri ifade edilmektedir. ${ }^{6}$ Nitekim M.Ö. 500-600 yılları arasında yaşadığ 1 değerlendirilen ve birçok kaynakta ilk kadın hükümdar olarak ifade edilen Tomris Han, eşinin ölümünden sonra "Pers kralına boyun eğmeyen" cesur bir Türk kadın hükümdarı olarak değerlendirilmiştir.

Tomris Han'ın hayatı ile ilgili kaynaklar genellikle Herodotos ile ortaya çıkmıştır. Bunun yanında Tomris Han ile ilgili anlatılara M.Ö. 2. ve 3. yüzyıl yazarlarından Marcus Iunianus Iustinus da kaynaklık etmektedir. Iustinus, İskit Kraliçesi Tomris Han'ın Perslerle olan savaşında oğlunu kaybetmesine rağmen duygusallıktan ve korkudan uzak hareket ettiğini, uyguladığı stratejilerle iki yüz bin kişilik Pers ordusunu başarılı bir şekilde yok ettiğini ifade etmiştir. Tomris Han’ın bu savaşta gösterdiği cesaret, erkeklere örnek olacak bir nitelikte olarak ifade edilmiştir. ${ }^{8}$

Türkler ilk dönemlerde göçebe olarak hayatlarını sürmeleri nedeniyle diğer devletler tarafından medeniyetlerini tam olarak sağlayamamış bir topluluk olarak görülmüşlerdir. Bu görüşe rağmen Türkler, her zaman kadına diğer topluluklardan daha çok önem ve değer vermiştir. Türklerde çocukların cinsiyetiyle ilgili ayrım yapılmamas1, kadınlara karşı olan bakış açısını açıkça belli etmiştir. Türk devlet geleneğinde benzer şekilde aileyi babadan sonra temsil eden anne olmuştur. Bu sebeple annenin yeri, babanın akrabalarından her zaman daha değerli olmuştur. Bu dönemde kad1nın, toplum veya aile içerisindeki konumunu sarsacak davranışlardan genel olarak kaçınılmıştır.

O dönemde eşler arasında ne kadar kavga da olsa erkek kadını asla evden kovmaz ya da boşamazdı. Erkeklerin ölmesi durumunda dul kalan kadınlar yine aynı ailede yaşamını sürdürürlerdi. Yani baba evine dönmezlerdi. Dul kalmış kadınlar, ailede her zaman için önem olarak ilk sırada görülmüşlerdir. Zaten Göktürk yazıtları ve Uygur dönemine ait buluntularda "ana"sözcüğü, her zaman "baba" sözcüğünden önce yazılmıştır. Bir başka örnek ise Dede Korkut kitabelerinde yer alan "ana ata" sözcüğüdür. ${ }^{9}$

Eski Türklerin kadına verdiği önemi anlamak için genellikle o dönemdeki hikâyeler, yazıtlar, efsaneler araştırılmış ve bu bağlamda çeşitli eserler kaynak olarak kullanılmıştır. $\mathrm{O}$ dönemde kadınlara gösterilen saygı günümüzdekinden daha ileri seviyededir. Oğuz Kağan Destanı da kadına oldukça yer vermiştir. Bilge Kağan’ın anası, devletin kuruluşunda etken olan en önemli insanlar arasındadır. Davranış biçimiyle

6 Faruk Çolak, “Türklerde Lider Kadın Tipolojisi ve Gülnar Hatun Efsanesi”, Uluslararası Medeniyet Çalışmaları Dergisi, 1/2 (2016), s.59.

7 Mehmet Özmenli, "Ortaçağ'da Türklerde Kadın ve Aile”, The Journal of Academic Social Science Studies, 66 (2018), s.350.

8 Emre Erten, “Antik Yazarlarda Bir İskit Kraliçesi: Tomyris”, Mediterranean Journal of Humanities, VI/2 (2016), s.237-263.

9 Bahaeddin Ögel, Dünden Bugüne Türk Kültürünün Gelişme Çağları, İstanbul: Türk Dünyası Araştırma Vakfı Yayınlar1, 2001, s.247-248. 
de kendisi Şefkat Tanrıçası Umay’a benzetilir. ${ }^{10}$ Umay adı ilk olarak Göktürk kitabelerinde geçmektedir. Kültigin Yazıtı'nın doğu yüzünde Umay ile ilgili ifadeler yer almaktadır. ${ }^{11}$

Oğuz Kağan’ın kutlu eşlerinden biri mavi bir 1şıktan, diğeri kutsal bir ağaçtan doğmuş olağanüstü özelliklere sahip kadınlar olarak görülmüştür. Karakırgızların Manas destanlarında kadın evin koruyucusu olarak ifade edilmektedir. Kahramanların hata yaptığı dönemlerde kurtarıcıları hep kadınlar olmuştur. Kadınların sözünün dinlenmediği yerde kahramanlar ölü olarak kabul edilmişlerdir. Kadının sadakatinde ve ailesine karşı davranışında sınırlar yoktur. Devlet içerisinde kadınla ilgili çıkan yalanlar, iftiralar kadının yerini sarsmazdı. Kocası ölen kadınlar evlenmekten kaçınırlardı. Tekrar evlenmek istemeyen kadınlar, evlenmesi için zorlanmazlardı. Bunun nedeni kocalarından kalan mallar üzerinde hak sahibi olmaları şeklinde ifade edilmiştir. ${ }^{12}$

Erkeklerin savaşa gittiği zamanlarda kadınlar, erkek işlerini üstlenmişlerdir. Otlaklara bakıp, evinin güvenliğini üstlenen kadınlar bu sayede savaşçı özelliklerini de geliştirmişlerdir. Kadınların savaşçı özelliklerini geliştirmelerini, mezarlarından çıkan kalıntılardan anlayabiliyoruz. Nitekim kadınlara ait mezarlarda yay, ok, kargı, kılıç, hançer ile birlikte vücudun korunması için kullanılan metalden yapılmış koruyucu zırhlar ele geçilmiştir. ${ }^{13}$

$\mathrm{Bu}$ düşünceyle paralel olarak Kitabelerde söze başlanırken kağanlar annelerini ve hatunlarını saymışlardır. Kağan buyrukları "Kağan buyuruyor ki” sözüyle başladığı zaman geçersiz sayılmıştır. ${ }^{14} \mathrm{O}$ dönemde kadının her zaman erkeğinin yanında yer alıp ona ilham verdiği düşünülmüştür.

Din her dönemde kadınların toplum içerisindeki hayatını yönlendirmiștir. Türklerin çok tanrılı inanışa sahip olduğu dönemde şaman Türk kadınlarının büyük ayinlere iştirak etmediğini görmekteyiz. Bunun sebebi kabile tanrısı huzuruna gelinin saygıdan dolayı çıkamamış olması olarak değerlendirilmiştir. Tölesler'de yine kadın şamanlar bulunmaktadır. Fakat bunlar da aynı şekilde törenlere katılmamışlardır. ${ }^{15}$ Buna karşın en iyi şaman, kadınlar arasından çıkardı.

Göktürk Devleti'nde insanlar hür bir hayat sürmüştür. Kadınların bu dönemde toplumda önemli yerleri vardı. Emirnameler, Kağan ve karısı tarafından ortak imzalanmaktaydı. Kağanın karısı, düzenlenen tören ile başa geçer ve devleti Kağan ile birlikte ortak bir şekilde yönetirlerdi. Devlet yönetiminde hatunların da söz sahibi olduğunu o döneme ait vesikalardan anliyoruz. ${ }^{16}$

10 Burhan Göksel, Çağlar Boyunca Türk Kadını ve Atatürk, Ankara: Kültür ve Turizm Bakanlığı Yayınları, 1993, s.105.

11 Talat Tekin, Orhon Yazıtları, Ankara: Türk Dil Kurumu Yayınları, 2010, s.32-33.

12 Abdulkadir İnan, Makaleler ve İncelemeler, Ankara: Türk Tarih Kurumu Basımevi, 1987, s.276.

13 İlhami Durmuş, Türk Tarihinin Öncüleri, Ankara: Akçağ Yayınları, 2013, s.52-53.

14 Ziya Gökalp, Türk Medeniyeti Tarihi, C. 2, İstanbul: Türk Kültür Yayınevi, s.211.

15 Özkan İzgi, Orta Asya Türk Tarihi Araștırmaları, Ankara: Türk Tarih Kurumu Basımevi, 2017, s.27.

16 Ahmet Taşağıl, Kök Tengri’nin Çocukları, İstanbul: Bilge Kültür Sanat, 2017, s.184. 
Yabancı devletlerin elçilerinin kabulünde, hatun hakanın yanında bulunur ve elçileri birlikte kabul ederlerdi. Tören ve şölenlerde kadın hakanın solunda oturur, siyasi önerilerini hakana iletirdi. Örneğin Çin ile ilk barış antlaşmasını Büyük Hun İmparatorluğu adına Mete Han'ın kadını imzalamıştır. ${ }^{17}$ Bir başka örnek ise Sabarların hükümdarı Belek'in ölmesiyle birlikte hükümdarlık makamına hatun Boarık’n geçmesidir. Yaklaşık yüz bin kişiyi idare eden bu hatun, devleti düzgün idare etmesiyle diğer devletler tarafından tanınmıştır. Bizans İmparatoru ile bizzat antlaşma yaparak o dönemde önemli bir şahsiyet olduğunu göstermiştir. ${ }^{18}$

Kadınlar sadece ordunun başında komutan olarak bulunmuyordu. Aynı zamanda ordu ile birlikte savaşa girip ok ve yay kullanıyorlardı. Bu konuda da erkeklerden eksik bir durumda kalmamışlardır. Eski Türklerde erkekler, savaş sırasındaki yeteneklerine ve mücadelelerine göre ileri zamanlarda devlet içerisinde önemli yerlere gelirlerdi. Kadınlar da aynı şekilde yetişmiş olup birçok kez erkeklerle birlikte savaşa katılırlardı. ${ }^{19}$ Uygurlar VII. yüzyılda henüz devlet kurmadan önce Uygur reisi savaşlarla uğraşıyorken, annesi Uluğ Hatun, halkın arasında çıkan karışıklıklarla uğraşıyor, kanuna karşı gelenleri, kanunlara uymayanları cezalandırıyordu. ${ }^{20}$ Arap istilası sırasında da oğlu Tuğ-Şad küçük olduğu için anası Hatun, Buhara Hükümdarlığı'nda on beş yıl kadar tahtta kalmıştır. Bu hükümdarlığı sırasında ordunun başında savaşlara katılmış ve diğer devletlerle antlaşmalar imzalamıştır. ${ }^{21}$

Eski Türk devletlerinde kadınlar, sosyal alanda da birçok hakka sahiptiler. O dönemde başka devletlerin erkekleri, kadınları istediği zaman boşayabiliyorlardı. Bu durum, Türk devletlerinde böyle değildi. Kadının da kocasını boşama hakkı vardı. Fakat boşanma Türklerde yok denecek kadar azdı. Çin'de erkek karısından rahatlıkla boşanmasına rağmen bu durum kadın için geçerli değildi. Yani erkek istediği zaman karısını boşayabilir fakat kadın boşayamazdı. Örneğin Uygurlar da bu hak, her iki taraf içinde geçerli sayılmıştır. Bunun dışında kadınların başka toplumsal hakları da vardi.

Eski Türklerde kadınlar da mal, mülk sahibi olabiliyorlardı. Çin elçisi Vang Yen Tö seyahatnamesinde, Uygur hatunlarının at sürülerine sahip olduklarını yazmaktadır. ${ }^{22}$ İslamiyet öncesi dönemi kadınlarında bir başka konu da giyim-kuşam şekilleridir. Eski Türk kadınının giyimine dair bilgileri, o dönemden kalan yazıtlardan, seyahatnamelerden ve duvar yazılarından öğrenmekteyiz. Genel olarak o dönemde kadınlar deriden yapılmış giysiler giyiyorlardı. Erkekler de deriden yapılmış olan giysileri giyerlerdi fakat bazı farklılıklar vardı. Kadınların şalvarları daha uzun olurdu. Ayaklarına, çizme yerine genellikle başmak adı verilen ayakkabı giyerlerdi. Başlıkları yine deriden veya keçeden yapılmış takke benzeri şeylerden oluşuyordu. ${ }^{23}$

17 Necdet Sevinç, Türklerde Kadın ve Aile, İstanbul: Bilgeoğuz Yayınları, 2007, s.31.

18 Taşağıl, Kök Tengri’nin Çocukları, s.272.

19 Kafesoğlu, Türk Milli Kültürü, s.241.

20 İzgi, Orta Asya, s.31.

21 Numan Durak Aksoy, “Eski Türk Toplumunda Kadının Sosyal Statüsü”, Türk Dünyası Araştırmaları Dergisi, 93/32 (2010), s.15.

22 Sevinç, Türklerde Kadın, s.91.

23 Şerafettin Turan, Türk Kültür Tarihi, İstanbul: Bilgi Yayınevi, 1994, s.252. 
Türk kadınının giyinme tarzındaki en büyük etken diğer devletlerle olan ilişkilerdir.

Eski Türk kadınlarının giyiminde sadece devletlerin değil dinin de etkisi vardır. Süse çok düşkün oldukları bilinen kadınlar, başlarına ipekten yapılan başörtü takarlar ve kulaklarına da çeşitli taşlardan yapılmış küpeler geçirirlerdi. ${ }^{24}$ Başları açık olan o dönemki Türk kadınları, saçlarını topuz yaparak, hotoz adı verilen başlık takarlardı. Zaman zaman omuzlarından ayak bileklerine kadar uzanan kıyafetler giyerlerdi. Bu kıyafetler genel olarak, çok süslü kumaşlardan oluşuyordu. ${ }^{25}$ Sonuç olarak Eski Türklerde kadın, gerek devlet işlerinde gerekse toplumsal yaşantıda önemli bir yere sahip olmuştur.

\section{İslamiyet Sonrasında Türk Kadını}

Türklerin İslam ile tanışması, Talas Savaşı’ndan sonra başlamıştır. Bu İslamlaşma süreci yaklaşık olarak binli yıllara kadar sürmüştür. Türk kadınları İslam’dan sonra sosyal ve siyasi faaliyetlere erkeği ile birlikte katılmış, mallarında tasarruf ettikleri gibi topraklar üzerinde de hak sahibi olmuşlardır. ${ }^{26}$ Peygamberimizin kadınlara hoşgörülü davranmasını kendine örnek almaya başlayan Türk hükümdarlar, kad1na olan saygısını daha da arttırmıştır. Nitekim Hazreti Peygamberin "Cennet annelerin ayakları altındadır” sözü, kadına ne kadar önem verildiğini göstermektedir. İslamiyet ile birlikte ortaya çıkan yeni anlayışlar, Türk toplumunda kendisine yer bulmuştur. Fakat bu anlayışlar, kadın-erkek eşitliğini bozmamıştır. Orta Asya Türk yaşantısında kadınlar, yine erkeklerle bir arada yaşamaya devam etmiş, birbirlerinden kaçmamışlardır. Aile hayatına kadınların yön vermeleri sürdürülmüştür. ${ }^{27}$ Genel olarak her dindeki kadın, hep geri planda kalmış, önemsenmemiştir. Peygamberler ise böyle milletlere gönderilmiş ve toplumun eşitlik düzeyini arttırmaya çabalamışlardır. Türklerin İslamiyet'e geçmesiyle birlikte, kadına karşı olan davranışları, din ayrımı yapmayacak şekilde daha da üst seviyelere taşınmıştır. Erkekler Hristiyan kadınla evlenebilir, ancak evlendikleri kadınların İslamiyet’i kabul etmeleri için hiçbir şekilde baskı yapmazlardı. Kadınlara da inanç özgürlüğü sağlanmıștır. ${ }^{28}$

İslamiyet'in kabulünden sonra Türklerde kadının önemi, önceki dönemlerle benzer doğrultuda ilerlemiştir. Nitekim Dede Korkut Kitabı'nda Selcen Hatun isimli kadın kahraman, at süren, kılıç ve ok marifetiyle savaşan bir karakter olarak betimlenmiştir. ${ }^{29}$ Buradan da anlaşılacağı gibi o dönemde kadınlar, erkekler gibi savaşçı özellikler göstermiştir. Kadına verilen önemi o dönemdeki edebiyat eserlerinde de görmek mümkündür. Harizmli büyük Türk âlim ve filozofu Zamahşeri (1047-1131) Türk kadınları hakkındaki şiirlerinde bu güzellerin orta boylu, ince belli, uzun saçlı, yay (keman) kaşlı, çekik gözlü ve gövdelerinin bacaklarından daha uzun olduğunu betimlemiştir. ${ }^{30}$ Hâlbuki ileri medeniyet olarak görülen Yunanlılarda bile kadına bu

24 İzgi, Orta Asya, s.39-40.

25 Sevinç, Türklerde Kadın, s.63-64.

26 Sevinç, Türklerde Kadın, s.35.

27 Turan, Türk Kültür Tarihi, s.253.

28 Göksel, Cağlar Boyunca, s.129.

29 Muharrem Ergin, Dede Korku Kitabı, İstanbul: Milli Eğitim Yayınevi, 1969, s.151-156.

30 Osman Turan, Türk Cihan Hâkimiyeti Mefkûresi Tarihi, İstanbul: Ötüken Neşriyat, 2009, s.47. 
derece saygı gösterilmemiştir. Saygı göstermemelerinin yanı sıra erkekler sağlıklı olduklarında dahi kendi kadınlarını başkalarına verme hakkına sahipti. ${ }^{31}$

Türkler Anadolu'da yayılmaya başladıkça devlet sisteminde bazı değişiklikler meydana gelmiştir. İkta sisteminin orta çıkması ile toprak sistemi bozulmaya başlamış, devletin otoritesi zayıfladıkça kadınlar geri plana düşmüştür. Fakat buna rağmen erkekler, tek bir kadınla evlenmişlerdir. O dönemde eğer kadının çocuğu olmazsa, o zaman erkek karısının rızasıyla ikinci bir kadınla evlenebilmekteydi. Kadınlar bunun yanında eve kapatılmamışlardır. Harem diye bir uygulama ortada yoktur. Kadınlar da erkekler gibi toplum içinde var olmuşlardır.

İslamiyet ile birlikte Türk kadını, devlet yönetiminde söz sahibi olmaya devam etmiştir. Kadınların yönetimdeki etkinliği, her zaman olumlu yönde olmamıştır. Selçuklu İmparatorluğu'nda Melik-şah'ın eşi Terken Hatun, siyasi istekleri nedeniyle devletin parçalanmasında büyük rol oynamıştır. ${ }^{32}$ Tuğrul Bey’in karısı Altuncan Hatun, kahraman Türk kadınına örnek olarak verilebilir. Tuğrul Bey, isyan eden kardeşinin peşinden Hamedan’a giderken, karısı Altuncan Hatun'a da vezirleri ile birlikte Bağdat’a gitmesini emretmiştir. Altuncan Hatun'unun da desteği ile Tuğrul Bey, kardeşi İbrahim Yınal’ı mağlup etmiştir. ${ }^{33}$ Altuncan Hatun, böyle tehlikeli bir dönemde yapmış olduğu hareketler sonucunda Selçuklu Devleti’nin ömrünü uzatmıştır. Buradan da anlaşılacağı gibi İslam sonrası devirlerde de kadınlara verilen yönetim hakkı devam etmiştir.

Selçuklularda kadınlar, sadece sultanın sarayının çevresinde değil kalıcı olarak da başka saraylarda ikamet etmişlerdir. Sultanın emrinde her zaman vezir, asker ve diğer görevliler bulunmaktadır. Hatunlar gerektiğinde sultana yardıma gidebilirlerdi. Altuncan Hatun'un Tuğrul Bey'e yardım etmesi gibi bu hatunlar Terken unvanıyla dile getirilirlerdi. Terken hatunların kendilerine ait yurtlukları, gelir getiren hazineleri mevcuttu. ${ }^{34}$ Bunların dışında Hatunların emrinde divanları da bulunuyordu. Buna "Hatun Divanı" adı verilmiştir. Bu divana sahip hatunlardan birisinin Melikşah’ın eşi Terken Hatun olduğu değerlendirilmektedir. ${ }^{35}$

Tarihte devlet başkanlığı yapan ilk kadınlar Türklerden çıkmıştır. Bunu Kutluk Türk Devleti'nde Türkan Hatun'un, Delhi Türk Devleti’nde Raziye Sultan’n devlet başkanı olduğu örneklerde görmek mümkündür. ${ }^{36}$ Kadının devlet yönetiminde siyasi bir mevkiye sahip olması, devletin feodal bünyesine yeni bir unsur eklemiştir. Bu durumun olumlu taraflarının yanında bazı olumsuz taraflarından da bahsedilmiştir.

Kadınlar, Türk devletlerinde siyasi yönden etkili oldukları dönemlerde bazen savaş sebebi de olabiliyorlardı. İki devlet arasındaki ilişkiyi pekiştirmek için siyasi evlilikler yapılıyordu ve bu evlilikler her zaman ilişkileri olumlu yönde etkilemiyordu. Bu

31 Kadri Süreyya Özdener, "İslam Öncesi Türklerde Kadının İçtimai Yeri”, Sosyoloji Konferansları Dergisi, 22 (1988), s.227.

32 Osman Turan, Selçuklular Tarihi ve Türk-İslam Medeniyeti, İstanbul: Ötüken Neşriyat, 2009, s.311.

33 Mehmet Altay Köymen, Tuğrul Bey ve Zamanı, İstanbul: Kültür Bakanlığı, 1976, s.67.

34 Turan, Selçuklular Tarihi, s.142.

35 Ali Sevim ve Erdoğan Merçil, Selçuklu Devletleri Tarihi, Ankara; Türk Tarih Kurumu, 1995, s.512.

36 Göksel, Çă̆lar Boyunca, s.108. 
siyasi evlilikler bazen devletleri savaşa kadar sürüklüyordu. Örneğin; Alp Arslan, kız kardeşini o dönemdeki Karahanlı hükümdarına gelin olarak vermişti. Bir süre sonra Karahanlı hükümdarı, eşini Selçuklu casusluğu yapmakla suçlayıp döverek öldürmüştü. Bunu duyan Alp Arslan, Karahanlı üzerine sefere çıkmaya karar verdi fakat kardeşinin eceliyle öldüğüne ikna edilip bu kararından vazgeçti. ${ }^{37}$

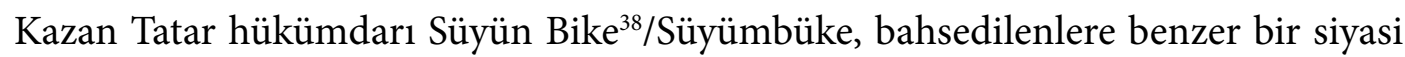
evlilikle henüz on beş yaşında Kazan Hanı olarak tahta geçen ve bazı kaynaklarda Rus yanlısı olarak ifade edilen Can Ali Han ile evlendirilmiştir. Süyün Bike’nin bu evliliği Kazanlılar ve Nogaylıları birbirine yaklaştırmıştır. Süyün Bike’nin Nogay Hanı olan babasının bu evliliğe en çok Kazanlılar ve Nogaylıları birbirine yaklaştırmak amacıyla müsaade ettiği değerlendirilmiştir. Bu evlilikten kısa bir süre sonra Can Ali Han’ın kendi halkı tarafından öldürülmesi üzerine dul kalan Süyün Bike, imparatorluğun varisi Sefa Giray Han ile evlendirilmiştir. Sefa Giray Han’ın da bir süre sonra vefat etmesi üzerine iki yaşındaki oğlu Ötemiş Giray han ilan edilmiştir. Oğlunun devlet yönetimine bakacak yaşta olmamasından dolayı devlet işlerini Süyün Bike yürütmüştür. Cesareti, asaleti ve zekâsı ile Kazan Hanlığı’nın en saygı duyulan ve sevilen kadın hükümdarı olmayı başararak Kazan Tatar Türklerinin kalplerinde yer almiştır. ${ }^{39}$

Cesareti ve yiğitliğiyle anılan Süyün Bike’ye benzer karakterdeki Türk kadın hükümdarlardan bir diğeri Uygur Sultanı İpar (Dilşad) Hatun'dur. Kahramanlıkları kadar güzelliğiyle de nam salan İpar Hatun (Çinlilerin tabiriyle ŞİANG-FEİ: Güzel kokulu Kraliçe), Budist Çinlilerle Müslüman Türkler arasındaki mücadelede önemli rol oynamış olması nedeniyle ${ }^{40}$ Türk tarihinde cesareti ile anılan kadın hükümdarlar arasında yer almıştır.

İslamiyet sonrasında kadın, tüm bu olumlu ve lider ruhlu özelliklerine karşın olumsuz nitelemeler ve tahlillerle de yorumlanmıştır. İslamiyet'in kadını bir baskı aracı haline getirdiği düşünceleri ekseninde ortaya atılan bu fikirlerin, genel olarak İslamiyet’ten ziyade İslam dininin yanlış yorumlanmasından kaynaklandığı değerlendirilmiştir. ${ }^{41}$

\section{Osmanlı Devleti’nde Türk Kadını}

Osmanlı Devleti'nin ilk yıllarında kadınlar, dokumacılık ve bunun gibi el işleriyle uğraşabiliyorlardı. Tarım ile ilgili işlerde eşlerine yardım ediyorlardı. Aynı zamanda pazara gidebilme özgürlükleri de vardı. Yıldırım Beyazıt döneminde, saray özel bir

37 Ömer Soner Hunkan, Türk Hakanlı̆̆ı Karahanlılar, İstanbul: IQ Kültür Sanat Yayınları, 2011, s.383.

38 Hüseyin Satıcıŏlu, “Tataristan'daki Süyün Bike ve Azerbaycan’daki Bakü Kız Kuleleri Kaynaklı Ortaya Çıkan Efsaneler Üzerine Bir İnceleme”, (II. Uluslararası Sosyal Bilimler Lisansüstü Öğrenci Kongresinde Sunulan Bildiri, Bişkek, Mayıs 11-12 2017).

39 “Süyümbike ve 1552 Kazan Şehitlerini Anma Kazan Tatarlarının Dünü ve Bugünü”, erişim 14 Haziran, 2015, https://www.altayli.net/suyumbike-ve-1552-kazan-sehitlerini-anma-kazan-tatarlarinin-dunu-ve-bugunu.html. 40 “Dilşad Hatun (İpar Hanım) Kimdir?”, erişim 14 Haziran, 2015 https://www.kerimusta.com/dilsad-hatunipar-hanim-kimdir/.

41 Sıddık Ağçoban, "Kadın Olgusunun Kültürel Gelişimi ve İslam’da Kadının Yeri Üzerine Tartışmalar", Uluslararası Kültürel ve Sosyal Araştırmalar Dergisi (UKSAD), 2/1 (2016), s.20. 
yer olmaktan çok insanların eğlendiği bir yer olmuştur. Bu durum kadına olan tabuları değiştirmeye başlamıştır. Harem, sadece merkezde bulunmaktaydı. Bu yüzden merkezdeki kadın ile köydeki kadın yaşantısında farklılıklar meydana gelmişti. Kırsal kesimdeki kadınlar daha özgürdü. ${ }^{42}$

Harem, Osmanlı Devleti ile birlikte Türk yaşantısında yer bulmuştur. Artık padişah hatunları sarayda dışa kapalı bir şekilde yaşamaya başlamışlardır. Haremin düzeni, nasıl yönetildiği hakkında bilgi sahibi olmak sıradan bir insan için olanaksızdı. Sadece erkekler değil önemli kadınlar dışında kimse haremin içini bilmezdi. Acil bir durum olmadığ 1 sürece doktor dişında hareme erkek giremezdi. Doktor girdiği zaman da yine aynı şekilde, hastayı göremezdi. Kadının hastalıkla ilgili gerekli yerlerine sadece örtü üzerinden dokunabilirdi. Harem içindeki kadınların dışarı çıkması da çok zordu. Sadece padişah istediği zaman ve kimsenin göremeyeceği şekilde bahçeye çıkabilirlerdi. ${ }^{43}$

Osmanlı Devleti'nde, kadın ve erkeğin dünyası ayrıydı. Erkek daha özgür, kadın ise daha özeldi. Kadın bu dönemde geçmiş döneme kıyasla daha çok kısıtlanmıştır. Bu kısıtlama, kadının sosyal hayatını, aile hayatını, giyim tarzını ve eğlenme şeklini dahi değiştirmiştir. Kadının, gidip görebileceği yerler dahi belli kurallarla belirlenmişti. Osmanlı mahallelerinde, çıkmaz sokakların oluşu, kadınları kısıtlamaya yönelik yapilan bir uygulamaydı. ${ }^{44}$

Osmanlı döneminde kadınlar, eğitimi sadece dini konuda almaktaydılar. Saray kadınları dışında başka tarzda eğitim alan bulunmuyordu. Saray kadınları da eğitimi daha çok kişisel tatmin ya da boş zamanlarını değerlendirmek için alıyorlardı.

Osmanlı ailesinde kadın, eski Türklere kıyasla ikinci plana atılmıştır. Bu durum sadece Türk olanlar için geçerli değildi. Diğer milletlerden kadınlarda aynı muameleyi görüyorlardı. Fakat bu durum kadınların tamamen özgürlüğünün elinden alındığ1nı anlamına da gelmemektedir. Nitekim Osmanlı kadınları rahatlıkla dini ayinlere katılabiliyordu. Hatta bazı özel günlerde Müslüman ve Hristiyan kadınlar bir arada kutlama bile yaparlard1. ${ }^{45}$

Kadınların hayvana binmeleri yasaktı. Gidecekleri yerlere o dönemdeki arabalarla giderlerdi. Bu arabalar etrafi tahtalarla kapalı, kafes pencerelere sahip olup sadece vezirlerin ve devletin önemli kişilerinin eşleri tarafından kullanılıyordu. Kadın ile erkeğin bu arabada birlikte yolculuk etmeleri yasaklanmıştı. ${ }^{46}$

Eğitim konusunda kadınlar çok kısıtlanmıştı. Din dışındaki diğer okullara kadınların gidip eğitim görmesi yasaktı. Sadece saray ve çevresindeki kadınlar özel eğitim görebiliyorlardı. Bu sayede iş kadınları ortaya çıktı fakat bunlar da yine saray halkından insanlardı. Büyük şehirlerde ise kadın sadece ev hanımı olarak görülürdü. ${ }^{47}$

42 Ömer Çaha, Sivil Kadın, Ankara: Vadi Yayınları, 1996, s.80.

43 Jean-Baptiste Tavernier, 17. Yüzyllda Topkapı Sarayı, İstanbul: Kitap Yayınevi, 2010, s.151.

44 Serpil Çakır, Osmanlı Kadın Hareketi, İstanbul: Metis Yayınevi, 2016, s.226-227.

45 İlber Ortaylı, Osmanli’yı Yeniden Keşfetmek, İstanbul: Timaş Yayınları, 2007, s.37.

46 Çakır, Osmanlı Kadın Hareketi, s.228.

47 Göksel, Çağlar Boyunca, s.131-132. 
Sultan eşleri, çekinmeden yabancı erkeklerle görüşme şansına sahiptiler. Toplumdan uzak bir şekilde yaşamamışlardır. Osmanlı dışından gelen önemli kişiler için iltifatta bulunup onları en iyi şekilde karşılamışlardır. Kendi adlarına köprüler, çeşmeler, mescitler yaptırmışlardır. ${ }^{48}$

Osmanlı Devleti'nin topraklarının artması ile birlikte medeniyetin Osmanlı Devleti'nde bulunduğu düşüncesi devletin batıya kapalı bir şekilde yaşamasına neden olmuştur. Eski Türklerden Osmanlı Devleti’ne kadar geçen sürede bazı gelenekler zaman içerisinde değişmiştir. Bunların en önemlilerinden biri kadına yöneltilen bakış açısıdır.

Kanuni döneminde, kadın artık mahrem sayılmaya başlamıştır. Kadınlarla ilgili fermanlar yayınlanmış, nerde nasıl giyineceği, erkeklerle ilişkileri ve kıyafetlerine varan kısıtlamalar getirilmiştir. Bunlardan çamaşırcı kadınlara dükkân için yetki verilir fakat usule uygun kıyafet yapmadığı takdirde dükkânı kapatılmıştır.

Osmanlı padişahlarından 3. Osman, dışarıya çıktığı zaman kadınların dışarıda gezmesini yasaklamıştı. Kadınların açık giyindiğine dair dedikodular sonucunda kadınların kıyafetlerine de kısıtlamalar geldi. Kayığa binmeleri yasaklandı. 3. Selim, kadınlara açık elbiseler dikmemesi için terzileri uyardı. Evlerin pencereleri, dışardan görünmeyecek şekilde örüldü. Boğaz kenarındaki yalılar, yüksek duvarlarla kapatıldı. Çünkü boğazdan geçen kayıkçıların evleri görme ihtimali vardı. ${ }^{49}$

Kadınların başlıca eğlence kaynağı, komşular arası ziyaretler, hamamlar ve mesire yerleriydi. Fakat bunları yaparken bile erkek-kadın ayrımı yaşanmıştır. Sadece sosyal hayatta değil öldükten sonra bile kadın-erkek ayrımı ölen kişi için uygulanmıştır. Mezar taşları bile farklı şekilde tasarlanmıştır. ${ }^{50}$

Osmanlı Devleti'nde gerileme dönemi ile birlikte artık devlet içinde bazı değişiklikler mecbur hale gelmiştir. Bu değişiklikler içinde kadınların sosyal hayattaki konumu da vardır. Ancak Tanzimat Fermanı ile birlikte kadınlar bazı sosyal ve siyasi haklara sahip olmuşlardı.

Osmanlı kadını, Tanzimat dönemine kadar bazı konularda kısıtlanmış bir şekilde yaşamını sürdürdü. Ülke içerisindeki gelişmeler doğrultusunda, mevcudiyetlerini II. Meşrutiyetle ortaya çıkarmaya başladılar. Meşrutiyet ile bazı haklara sahip olmuşlardı. Artık kızlar için eğitim başlamış, miras hakları doğmuştu. II. Meşrutiyet’in ilanı ile birlikte kadınlar, çalışma hayatında da boy göstermeye başlamışlardır. Özellikle o dönemde savaşa giden erkeklerin yerine boş kalan memurluklara yerleştirilmişlerdir. Erkek sayısının azalması kadınların çalışmasına olanak sağlamıştır. ${ }^{51}$

II. Meşrutiyet ile birlikte Osmanlı Devleti, batıya ayak uydurmaya çalışmış, birçok

48 Abdurrahman Kurt, “Osmanlı Kadınının Sosyo-ekonomik Konumu”, Osmanl, C.V (1999), s.445.

49 Sevinç, Türklerde Kadın, s.50-51.

50 Çakır, Osmanlı Kadın Hareketi, s.228

51 Banu Çakmak, “Tanzimat'tan Cumhuriyet'e Uzanan Çizgide Osmanlıda Kadın Hareketleri, Dönemin Tiyatrosunda Kadının Temsili ve Kadın Sorunu”, Tiyatro Eleştirmenliği ve Dramaturji Bölüm Dergisi, 18 (2011), s.45-79. 
alanda yenilik yapmıştır. Bu alanlardan birisi de kadın haklarıdır. II. Meşrutiyet kadın hareketinin başlamasına sebep olmuştur. Bu hareketin gelişmesindeki en önemli etken gazete ve dergilerdir. Kadınlar, seslerini duyurabilmek için bu gazeteler ve dergilere yazılar yazmışlardır. Bunun yanı sıra dernekler kurulmuş, kadınların eğitilmesi ve iş hayatına atılmaları için yardımcı olmuşlardır. Bu dönemde, kadınlar hukuksal alanda da ön plana çıkmışlardır. İslam hukuku yerine aile hukuku ortaya çıkmış ve bu alanında düzenlemeler yapılmıştır. Evliliğe yaş sınırı getirilmiş, devlet memuru ve iki şahit olmadığ 1 sürece evlilik resmiyet kazanmamıştır. Boşanma konusunda da yenilikler getirilmiş, boşanmayı gerektiren konular hakkında düzenlemeler yapilmıştır. ${ }^{52}$

Osmanlı kadınının ön plana çıkması, batının örnek alınması ile doğru orantılıdır. II. Meşrutiyete kadar kadın haklarındaki değişim, sadece ev ve aile ile sınırlıddı. Fakat bundan sonra kadın, sosyal alanda ve siyasi alanda kendini göstermeye başlamıştır. ${ }^{53}$

Batıda kadın haklarını savunanların başında erkekler geliyordu. Osmanlı Devleti'nde de, bu durumdan geri kalmak istemeyen aydınlar, kadın hareketini desteklemişlerdir. Modernleşmenin temel kaynağının kadınlar olacağını dile getirmişlerdir. ${ }^{54}$

Osmanlı döneminde kadınlar, genel olarak devlet meselelerine uzak yaşamışlardır. Kadınlar bu süreçte, eşlerine yardımda bulunmaktan başka yol bir izlemeyi nadir olarak tercih etmiştir. Meşrutiyet ile birlikte kadınların toplumsal rollerinde önemli değişimler yaşanmıştır. Tanzimat dönemi ile birlikte Türk kadınlarının devlet ve toplum içerisindeki rollerinde önemli değişiklikler yaşanmıştır. Tanzimat dönemi edebiyatçı ve aydınlarının etkisiyle Osmanlı kadını, günümüzdeki hak ve özgürlüklerine ulaşma noktasında fikri olarak büyük destek görmüştür. ${ }^{55}$

\section{Cumhuriyet'in Illanından Sonra Türk Kadını}

Cumhuriyet'in ilanı ile birlikte toplumda her alanda yenilikler meydana gelmiştir. Fakat bu yeniliklerin sürekliliği, toplumun iki cinsi olan erkek ve kadına eşit şekilde davranılmasıyla sağlanmıştır. Yapılan yenilikler, sadece erkekler için değil kadınlar içinde geçerli olmalıydı. Sosyal alanda, hukuk alanında, siyasi alanda yapılacak yenilikler kadınlara da aynı oranda uygulanmalıydı. Kadın, çocuklarını topluma hazırlaması, eğitmesi, ailede sağlıklı bir ortamın kurulmasında önemli rol oynaması nedeniyle her zaman için önem verilmesi gereken bir varlıktır. Atatürk'ün bu konuda ifade ettiği; "erkeklerden daha çok aydın, daha çok feyizli, daha fazla bilgili olmaya mecburdurlar." sözü, kadına verilmesi gereken değeri açıkça belli etmiştir. ${ }^{56}$

Kadınların sosyal alanda, siyasi alanda ve hukuk alanında elde ettikleri haklar, aşamalı bir şekilde gerçekleşmiştir. İsviçre Medeni Kanunu'nu örnek alarak hazırlanan

52 Nilüfer Özcan Demir, “II. Meşrutiyet Dönemi Osmanlı Feminizmi”, Hacettepe Üniversitesi Edebiyat Fakültesi Dergisi, 16/2 (1999), s.110-111.

53 Çakır, Osmanlı Kadın Hareketi, s.22.

54 Şefika Kurnaz, Cumhuriyet Öncesi Türk Kadını, Ankara: Aile Araştırma Kurumu Başkanlığı Yayınları, 1991, s.15.

55 İlhan Aksoy, “Toplumsal ve Siyasal Süreçte Türk Kadını”, Yasama Dergisi, 32 (2017), s.17.

56 Utkan Kocatürk, Atatürk’ün Fikir ve Düşünceleri, Ankara: Turhan Yayınları, 1984, s.94. 
Türk Medeni Kanunu’nda, kadın ile erkek yasalar önünde eşit sayılmıştır. Örneğin; arazi kanunu ile artık babanın mirasında kız evladı da hak sahibi olmuştur. Evlenen kızlardan alınan gelinlik vergisi ortadan kalkmış, köleliğin son bulmasıyla da cariyelik kavramı yok olmuştur. Kadınlar yavaş yavaş sokağa çıkmaya başlamış, okullarda eğitim görme hakkını elde etmişlerdir. ${ }^{57}$ Atatürk erkek-kadın ayrımı gözetmeksizin ikisinin de eşit olduğunu belirtmiş, TBMM açılış konuşmasında, kadınların ve erkeklerin eşit düzeyde eğitim görmesi gerektiğini söylemiştir. ${ }^{58}$

Atatürk, Türk kadınına verdiği değeri ve kadının toplumdaki rolünü, Konya’da Kızılay Kadınlar Şubesince düzenlenen çay etkinliği esnasında şu sözlerle dile getirmiştir: ${ }^{59}$

“(...) Bu son yılların inkılâp hayatında, ateşli fedakârlıklarla yüklü mücadele hayatında, milleti ölümden kurtararak kurtuluşa ve bağımsızlığa götüren kararlı çalışma hayatında, her millet bireyinin çalışması, gayreti, emeği, fedakârlığı geçmiştir. Bunlar içinde en fazla yüceltilmesi, anılması ve daima teşekkür ile tekrar edilmesi gereken bir emek vardır ki, o da, Anadolu kadınının göstermiş olduğu çok yüce, çok yüksek, çok kıymetli fedakârlıktır. Dünyanın hiçbir yerinde, hiçbir milletinde, Anadolu köylü kadınının üstünde kadın çalışması söylememize imkânı yoktur ve dünyada hiçbir milletin kadını "Ben Anadolu kadınından daha fazla çalıştım, milletimi kurtuluşa ve zafere götürmekte Anadolu kadınından daha fazla çalıştım, milletimi kurtuluşa ve zafere götürmekte Anadolu kadını kadar gayret gösterdim” diyemez. (...)

Kadınlarımızın her millette olduğu gibi, bizim milletimiz için de ne kadar yüksek önemi olduğunu söylemeğe gerek yoktur. Bizim milletimizde kadın, eskiden bu önemi gerçekten en yüksek derecede kazanmıştır. Büyük atalarımız ve onların anaları, tarihin ve olayların tanıklığıyla sabittir ki, cidden yüksek faziletler göstermişlerdir. Burada birçok noktalardan sayabileceğimiz o faziletlerin en büyüğü ve en önemlisi klymetli evlâtlar yetiştirmeleriydi. Gerçekten Türk milletinin bütün dünyada yalnız Asya'da değil Avrupa'da bile büyük üstünlükler göstermiş olması, gösterişli hareketler yapmış olması, hep öyle kıymetli ataların faziletli evlâtlar yetiştirmesi ve daha beşikten çocuklarının ruhuna mertlik ve fazilet aşılaması sayesinde idi. Şunu söylemek istiyorum ki, kadınlarımızın toplum görevlerinde üzerlerine düşen hisselerden başka kendileri için en önemli, en hayırlı, en faziletli bir görevleri de iyi anne olmaktır. Zaman ilerledikçe. İlim geliştikçe, uygarlık dev adımlarıyla yürüdükçe, hayatın, asrın bugünkü gereklerine göre evlât yetiştirmenin zorluklarını biliyoruz. Anaların bugünkü evlâtlarına vereceği terbiye eski devirlerdeki gibi basit değildir. Bugünün anaları için gereken kaliteye sahip evlat yetiştirmek, evlâtlarını bugünkü hayat için çalışan bir parça haline koymak, pekçok yüksek vasıfların sahibi olmağa bağlıdır. Bundan dolayı kadınlarımız hatta erkeklerden

57 Göksel, Çağlar Boyunca, s.133.

58 Burhan Göksel, “Atatürk ve Kadın Hakları”, Atatürk Araştırma Merkezi Dergisi, 1/1 (1984), s.226-227.

59 “Atatürk’ün Söylev ve Demeçleri”, erişim 6 Mart, 2019, http://www.atam.gov.tr/ataturkun-soylev-ve-demecleri/ konyada-kadinlar-ile-konusma. 
daha çok aydın, daha çok verimli, daha fazla bilgili olmak zorundadırlar. Eğer gerçekten milletin anası olmak istiyorlarsa böyle olmalıdırlar. (...)”

Atatürk, Kurtuluş Savaşı sırasında her daim yardımını gördüğü kadınları hiç unutmamıştır. Onlara her zaman borçlu olduğunu dile getirmiş, bu borcu da onlara eşit davranarak ödemeye çalışmıştır. Gittiği her şehirde yaptığı konuşmalarda, kadınlardan her zaman söz etmiş ve kadınlar hakkında kafalarında soru işareti olan bireylerin olumsuz düşüncelerini yok etmeye çalışmıştır. ${ }^{60}$

Atatürk sadece bu yeniliklerle kalmamış, kadınların sosyal ve siyasi hayatı dışında eğitimde de eşit olması için yenilikler yapmıştır. Kadının toplumda kalıcı olabilmesi için eğitimin şart olduğunu biliyoruz. 1924 yılında kabul edilen Tevhid-i Tedrisat kanunu ile eğitim alanında kadın-erkek eşitsizliği ortadan kalkmıştır. ${ }^{61}$

Kadının toplumsal hayattaki belki de en önemli haklarından biri seçme ve seçilme hakkıdır. Öncelikle sadece belediye meclislerinde seçme ve seçilme hakkı tanınan kadınlar, 1934'te milletvekili olarak seçme ve seçilme hakkına sahip olmuştur. Bu sayede artık Türk kadınına eşit yurttaşlık hakkı verilmiştir. Atatürk bu konuda, Türk kadınlarının Avrupalı kadınlardan daha üstün bir konumda olduğunu dile getirmiş, bu kararı en önemli reformlarından biri olarak görmüştür. ${ }^{62}$

\section{Sonuç}

Türk kültür ve devlet geleneğinde kadınının yeri, tarihsel süreç içerisinde bir takım değişiklikler göstermesine karşın Türk kadını devlet ve toplum içerisinde her dönemde özel bir öneme sahip olmuştur. Kadın, Türk toplumu içerisinde annelik özelliğinden kaynaklanan yüce bir değer olarak kabul edilmektedir. Çünkü kadın var oldukça aile de var olmuş, aile var oldukça devlet de var olmuştur. Kadının önemsendiği bir toplumda bireyler de önemsenmiştir. Kısacası kadına verilen değer ile toplumda fertlere verilen değer her zaman birbiriyle doğru orantılıdır. Nitekim kadına önem vermek aileye önem vermek, aileye önem vermek ise topluma önem vermek demektir. Devletin bekası için toplumun kültürel ve geleneksel yapısına önem vermek devletler açısından olmazsa olmaz bir anlayıştır.

İlk Türk devletlerinde görüldügü üzere kadınların sosyal hayattaki yeri bakımından erkeklerden pek bir farkı yoktur. İlk Türk devletlerinde kadın her zaman için önemsenmiş hatta gerektiğinde devlet yönetimi dahi kadınlara teslim edilmiştir. Kadınlar, birçok defa yaşandığı üzere savaşlarda ordunun başında görev yaparak devletin devamlılığı için mücadele etmiştir.

Eski Türk devlet yönetiminde önemli roller oynayan kadın, Osmanlı Devleti’nin ilk kuruluş dönemlerinde genellikle zamanının çoğunluğunu ev hayatı ile geçiren buna karşın manevi desteği ile ailesine ve eşine büyük katkılar sunan yüce bir değer olarak toplumda var olmuştur. Osmanlı Devleti döneminde kadının toplumsal ve siyasi bu

60 Vahap Sağ, “Tarihsel Süreç İçerisinde Türk Kadını ve Atatürk”, Cumhuriyet Üniversitesi İktisadi ve İdari Bilimler Dergisi, $2 / 1$ (1999), s.19.

61 Sağ, "Tarihsel Süreç”, s.21.

62 Sağ, “Tarihsel Süreç”, s.22. 
rolü, eski Türk devletlerine ve Cumhuriyet dönemi kadınına kıyasla bir takım sınırlamalarla karşılaşmış olsa da kutsallığından bir şey kaybetmemiştir.

Osmanlı Devleti'nin kuruluşundan Türk Kurtuluş Savaşı içerisindeki milli mücadele dönemine kadar toplumsal değerini devam ettirmiş olan kadın, özellikle milli mücadele döneminde gösterdiği kahramanlıklarla Türkiye Cumhuriyeti’nin kuruluşunda önemli rol oynamıştır. Nitekim milli mücadele yıllarında kadın, evde evladına ana, cephedeki askerine çarık, düşmana karşı ise mermi olmuştur. Türk kadınının analığıla taşımakta olduğu kutsallık, cephede gösterdiği üstün cesaret ve kahramanlıklarla birlikte pekişmiştir.

Cumhuriyet'in ilanı ile birlikte başlayan dönemde Türk kadınına verilmesi gereken önemi her firsatta dile getiren Türkiye Cumhuriyeti'nin kurucusu Mustafa Kemal Atatürk, Türkiye Cumhuriyeti’nde yaşayan kadınların toplumsal ve siyasi bir takım özgürlüklere kavuşması konusunda yoğun bir çaba harcamıştır. O dönemde birçok Batılı toplumda olmayan hak ve özgürlükler Atatürk'ün Türk kadınına verdiği yüce değer ile Türk kültürüne ve devlet yönetimine kazandırılmıştır. Böylelikle kadınlar toplumun her alanında söz sahibi olmaya devam etmiştir.

Türk devlet geleneğinde kadın, batılı birçok kaynakta değersiz olarak bahsedilmesinin aksine, tarihin ilk döneminden beri her zaman toplum içerisinde özel korumalı yerde bulunan yüce bir değer olarak kabul edilmiştir. Bu değerin üzerine Türk kadınının tarihte eşine rastlanmamış olan cesareti ve asaleti eklendiğinde, Türk kültür ve devlet geleneğinde kadının sahip olduğu önem daha rahat bir şekilde ortaya çıkacaktır. Nitekim bu değerin örnekleri Tomris Han'dan Umay Ana'ya, İlbilge Hatun'dan Selcen Hatun'a, Altuncan Hatun'dan Süyün Bike’ye, İpar Hatun'dan Nene Hatuna kadar devam etmiştir. Bu değer, günümüzde toplum ve devlet içerisinde en üst düzey görevlerde rol alan Türk kadınıyla devam etmektedir.

Binlerce yıllık kökleşmiş özellikleri itibarıyla Türk kültür ve tarihi ile devlet geleneği içerisinde kadının toplumsal ve siyasi rolünü değerlendirecek olduğumuzda, kad1nın değer gördüğü her toplumun ilerleme kaydetmiş/kaydetmekte olduğu sonucuna ulaşmak mümkündür. Bu nedenle eski Türk kültür ve devlet geleneğinden günümüze kadar gelen kadının toplumsal ve siyasi yaşam içerisindeki yerinin, günümüz dünyasında medeni birçok devlet tarafından ilham alınması gereken bir noktada yer aldığını ifade etmek mümkündür.

\section{Kaynakça}

Ağçoban, Sıddık. "Kadın Olgusunun Kültürel Gelişimi ve İslam’da Kadının Yeri Üzerine Tartışmalar”. Uluslararası Kültürel ve Sosyal Araştırmalar Dergisi (UKSAD). 2/1 (2016): 14-24.

Aksoy, İlhan. “Toplumsal ve Siyasal Süreçte Türk Kadını”. Yasama Dergisi. 32 (2017): 7-20.

Aksoy, Nuran Durak. “Eski Türk Toplumunda Kadının Sosyal Statüsü”. Türk Dünyası Araştırmaları Dergisi. 93 (2010): 149-166. 
Atatürk Araştırma Merkezi Başkanlığ . “Atatürk'ün Söylev ve Demeçleri”. Erişim 6 Mart, 2019. http://www.atam.gov.tr/ataturkun-soylev-ve-demecleri/konyadakadinlar-ile-konusma.

Bayat, Fuzuli. Türk Kültüründe Kadın Şamanlar. İstanbul: Ötüken Neşriyat, 2018.

Çaha, Ömer. Sivil Kadın. Ankara: Vadi Yayınları, 1996.

Çakır, Serpil. Osmanlı Kadın Hareketi. İstanbul: Metis Yayınevi, 2016.

Çakmak, Banu. "Tanzimat'tan Cumhuriyet'e Uzanan Çizgide Osmanlıda Kadın Hareketleri, Dönemin Tiyatrosunda Kadının Temsili ve Kadın Sorunu”. Tiyatro Eleştirmenliği ve Dramaturji Bölüm Dergisi. 18 (2011): 45-79.

Çolak, Faruk. "Türklerde Lider Kadın Tipolojisi ve Gülnar Hatun Efsanesi”. Uluslararası Medeniyet Çalışmaları Dergisi. 1/2 (2016): 59.

Demir, Nilüfer Özcan. "II. Meşrutiyet Dönemi Osmanlı Feminizmi”. Hacettepe Üniversitesi Edebiyat Fakültesi Dergisi. 16/2 (1999): 107-115.

Durmuş, İlhami. Türk Tarihinin Öncüleri. Ankara: Akçağ Yayınları, 2013.

Ergin, Muharrem. Dede Korku Kitabı. İstanbul: Milli Eğitim Yayınevi, 1969.

Erten, Emre. “Antik Yazarlarda Bir İskit Kraliçesi: Tomyris”. Mediterranean Journal of Humanities. VI/2 (2016): 237-263.

Gökalp, Ziya. Türk Medeniyeti Tarihi. İstanbul: Türk Kültür Yayınevi, 1974.

Göksel, Burhan. Çağlar Boyunca Türk Kadını ve Atatürk. Ankara: Kültür ve Turizm Bakanlığı Yayınları, 1988.

Göksel, Burhan. “Atatürk ve Kadın Hakları”. Atatürk Araştırma Merkezi Dergisi. 1/1 (1984): 213-235.

Gündüz, Ahmet. “Tarihi Süreç İçerisinde Türk Toplumunda ve Devletlerinde Kadının Yeri ve Önemi”. The Journal of Academic Social Science Studies. 5/5 (2012): 129148.

Hunkan, Ömer Soner. Türk Hakanlı̆̆ı Karahanlılar. İstanbul: IQ Kültür Sanat Yayınları, 2011.

İnan, Abdulkadir. Makaleler ve Incelemeler. Ankara: Türk Tarih Kurumu Basımevi, 1987.

İzgi, Özkan. Orta Asya Türk Tarihi Araştırmaları. Ankara: Türk Tarih Kurumu Basimevi, 2017.

Kafesoğlu, İbrahim. Türk Milli Kültürü. İstanbul: Ötüken Neşriyat, 2015.

Kerim, Usta. “Dilşad Hatun (İpar Hanım) Kimdir?”. Erişim 14 Haziran, 2019. https:// www.kerimusta.com/dilsad-hatun-ipar-hanim-kimdir/.

Kocatürk, Utkan. Atatürk'ün Fikir ve Düşünceleri. Ankara: Turhan Yayınları, 1984.

Köymen, Mehmet Altay. Tuğrul Bey ve Zamanı. İstanbul: Kültür Bakanlığı, 1976.

Kurban, Roza. "Süyümbike ve 1552 Kazan Şehitlerini Anma Kazan Tatarlarının Dünü ve Bugünü”. Erişim 14 Haziran, 2019. https://www.altayli.net/suyumbikeve-1552-kazan-sehitlerini-anma-kazan-tatarlarinin-dunu-ve-bugunu.html.

Kurnaz, Şefika. Cumhuriyet Öncesi Türk Kadını. Ankara: Aile Araştırma Kurumu Başkanlığı Yayınları, 1991. 
Kurt, Abdurrahman. “Osmanlı Kadınının Sosyo-Ekonomik Konumu”. Osmanlı. 5 (1999): 434-448.

Ortaylı, İlber. Osmanliyı Yeniden Keşfetmek. İstanbul: Timaş Yayınları, 2007.

Ögel, Bahaeddin. Dünden Bugüne Türk Kültürünün Gelişme Çağları. İstanbul: Türk Dünyası Araştırma Vakfı Yayınları, 2001.

Özdener, Kadri Süreyya. “İslam Öncesi Türklerde Kadının İçtimai Yeri”. Sosyoloji Konferansları Dergisi. 22 (1988): 225-235.

Özmenli, Mehmet. "Ortaçağ'da Türklerde Kadın ve Aile”. The Journal of Academic Social Science Studies. 66 (2018): 347-356.

Sağ, Vahap. “Tarihsel Süreç İçerisinde Türk Kadını ve Atatürk”. Cumhuriyet Üniversitesi İktisadi ve İdari Bilimler Dergisi. 2/1 (2001): 9-23.

Satıcıŏlu, Hüseyin. “Tataristan'daki Süyün Bike ve Azerbaycan'daki Bakü Kız Kuleleri Kaynaklı Ortaya Çıkan Efsaneler Üzerine Bir İnceleme”, II. Uluslararası Sosyal Bilimler Lisansüstü Öğrenci Kongresinde Sunulan Bildiri, Bişkek, Mayıs 11-12, 2017.

Sevim, Ali ve Merçil Erdoğan. Selçuklu Devleti Tarihi. Ankara: Türk Tarih Kurumu, 1995.

Sevinç, Necdet. Türklerde Kadın ve Aile. İstanbul: Bilgeoğuz Yayınları, 2007.

Taşağıl, Ahmet. Kök Tengri’nin Çocukları. İstanbul: Bilge Kültür Sanat, 2017.

Tavernier, Jean-Baptiste. 17. Yüzyılda Topkapı Sarayı. İstanbul: Kitap Yayınevi, 2010.

Tekin, Talat. Orhon Yazıtları. Ankara: Türk Dil Kurumu Yayınları, 2010.

Tellioğlu, İbrahim. "İslam Öncesi Türk Toplumunda Kadının Konumu Üzerine”. A. Ü. Türkiyat Araştırmaları Enstitüsü Dergisi [TAED]. 55 (2016): 209-224.

Turan, Osman. Selçuklular Tarihi ve Türk-İslam Medeniyeti. İstanbul: Ötüken Neşriyat, 2009.

Turan, Osman. Türk Cihan Hâkimiyeti Mefkûresi Tarihi. İstanbul: Ötüken Neşriyat, 2009.

Turan, Şerafettin. Türk Kültür Tarihi. İstanbul: Bilgi Yayınevi, 1994.

Yılmaz, Ayfer. “Türk Kültüründe Kadın”. Milli Folklor. 16/61 (2004): 111-123. 
İNSAN\&İNSAN, Y11/Year 6, Say1/Issue 21, Yaz/Summer 2019, 395-411

DOI: https://doi.org/10.29224/insanveinsan.536610

\title{
Women in Turkish Culture and Tradition of State
}

\author{
HASAN ACAR
}

Abstract: Since Adam and Eve, who are regarded as the ancestors of mankind, "women" have existed on the earth despite all the difficulties of nature and living conditions. The "woman" has been in a constant struggle to maintain this existence. The dimension of this struggle is shaped by the different approach of women in every society. Within the world civilization, "woman" has an important value in Turkish culture and state tradition. Undoubtedly, the traditional perspective of Turkish culture played a major role in the emergence of this value. With the effect of rapid technological and social changes in today's world, "women" has a very important role in the Turkish culture and tradition to build society on solid foundations and to maintain the family structure in a healthy way. This study aims to express the importance of "women in terms of state and society from the ancient Turks to the present..

Keywords: State tradition, Turkish culture, Social change, Women in Turkey, Social role of women. 